\title{
The effect of non-surgical periodontal therapy on systemic immune response and blood glucose level of NIDDM patients
}

\author{
Oedijani-Santoso $^{1}$, Sarwono Waspadji ${ }^{2}$
}

\begin{abstract}
Abstrak
Inflamasi periodontal merupakan kelainan periodontal dengan prevalensi tinggi di masyarakat. Periodontitis kronis dipengaruhi oleh akumulasi plak dan kalkulus sebagai faktor local, ditambah faktor sistemis misalnya diabetes mellitus (DM) dan infeksi HIV. Sitokin terutama IL-1 $\beta$ sebagai mediator inflamasi utama penyakit periodontal, menstimulasi ekspresi iNOS (inducible nitric oxide synthase) dan produksi NO (nitric oxide) oleh sel $\beta$, menyebabkan disfungsi sel $\beta$. Leukotoksin dan protease yang dihasilkan patogen periodontal menyebabkan jejas kemotaktik dan fagositotik, dan menurunkan fungsi fagositosis PMN. Hiperglikemia pada penyandang DM menyebabkan peningkatan kadar kalsium sitosol $\left(\mathrm{Ca}^{2+}\right)$, yang menyebabkan disfungsi PMN dan menurunkan fungsi fagositosis. Advanced glycosilation endproduct pada DM tipe 2 berikatan dengan monosit menyebabkan peningkatan sitokin proinflamasi (IL-1, $T N F \alpha)$ dan menyebabkan aktivasi makrofag dan osteoklas. Hiperglikemia menyebabkan aktivasi diasil gliserol (DAG)-protein kinase $C(P K C)$, yang menyebabkan peningkatan PGE2 dan ekspresi sitokin yang mempengaruhi proses inflamasi dan destruksi. Penelitian tentang pengaruh scaling (pembersihan karang gigi sebagai tindakan non-bedah pada terapi periodontal) pada penyandang DM terhadap kadar gula darah dan respons imun selular belum pernah dilakukan di Indonesia. Penelitian ini bertujuan menganalisis pengaruh pembersihan karang gigi terhadap kadar IL-1 $\beta$, fungsi fagositosis PMN dan kadar glukosa darah penyandang DM tipe 2. Subyek penelitian adalah penyandang DM tipe 2, 60 penyandang DM Terkendali dan 60 penyandang DM Tidak Terkendali di Poliklinik Metabolik-Endokrin RSUPN Ciptomangunkusumo, umur 40-60 tahun. Subyek dibagi menjadi kelompok perlakuan dan kelonpok tanpa perlakuan, untuk menilai respons imun selular dan status DM, sebelum dan 6 minggu sesudah perlakuan. Analisis statistik ( $t$ test) dengan komputer menggunakan perangkat Stata 7,0 dilakukan untuk membandingkan parameter sebelum dan sesudah scaling pada kedua kelompok. Hasil penelitian menunjukkan bahwa scaling dapat menurunkan kadar IL-1 $\beta$ dan meningkatkan fungsi fagositosis secara bermakna ( $P<0,05)$, menurunkan kadar glukosa puasa, glukosa 2 jam PP dan kadar HbAlc, tetapi penurunannya secara statistik tidak bermakna $(P>0,05)$, kecuali penurunan kadar HbAlc pada DM Tidak Terkendali $(P=0,00)$. (Med J Indones 2008; 17: 20-4)
\end{abstract}

\begin{abstract}
Abtract
Periodontal inflammation is a periodontal disorder of high prevalence in the population. Chronic periodontitis is associated with the accumulation of plaque and calculus as local factors, and systemic factors such an diabetes mellitus (DM) and HIV infection. Cytokine, especially IL-1 $\beta$ as inflammatory mediator for periodontal disease, may directly stimulated iNOS (inducible nitric oxide synthase) expression and NO (nitric oxide) production by $\beta$-cells, resulting in NO-mediated $\beta$-cell damage. The leucotoxin and proteases produced by periodontal pathogens will induce chemotactic and phagocytotic defect; therefore causing decreased PMN phagocytotic function. Hyperglicemia which occurs in diabetic patients increases calcium influx to the cell, resulting in the increased cytosol's calcium ([Ca $\left.{ }^{2+}\right]$ i) level and; therefore, resulting in dysfunction of PMN and impaired PMN phagocytotic function. Advanced glycosilation endproduct in NIDDM binds to monocytes resulting in the increase of pro-inflammatory cytokines (IL-1, TNF $\alpha)$ and produces activation of macrophages and osteoclasts. Hyperglicemia activates diacyl glycerol (DAG)-protein kinase C (PKC), thus increasing PGE2 and cytokine expression that induce inflammation and periodontal tissue destruction processes. Studies on the effect of scaling to remove calculus disposition on blood glucose control and cellular immune response in DM patient has never been carried out. The aim of the study was to analyze the effect of scaling as non-surgical periodontal therapy on immune response (IL-1 $\beta$ level and PMN phagocytotic function) and blood glucose level of type 2 diabetic patients. Subjects were diabetic patients, 60 controlled-DM (CDM) and 60 uncontrolled-DM (UCDM), in Metabolic-Endocrinology Clinic of Ciptomangunkusumo Hospital, aged 40-60 years. The subjects were divided into treatment (scaling) and control group, and cellular immune response and diabetic status, before and 6 weeks after treatment were evaluated. Statistical analysis ( $t$ test) were done using Stata 7.0 software, to compare the parameters before and after scaling in CDM and UCMD subjects. The results showed that scaling decreased IL-1 $\beta$ level and increased phagocytotic function significantly $(P<0.05)$. Scaling decreased fasting and 2 hours post-prandial blood glucose levels and HbAlc level, but the decrease were not significant statistically $(P>0.05)$, except for the decrease in HbAlc level in uncontrolled DM $(P=0.00)$. (Med J Indones 2008; 17: 20-4)
\end{abstract}

Keywords : IL-1 $\beta$ level, phagocytotic function, HbAlC level

\footnotetext{
${ }^{1}$ Department of Dental and Oral Diseases, Faculty of Medicine University of Diponegoro, Semarang, Indonesia

${ }^{2}$ Department of Internal Medicine, Metabolic-Endocrinology Division, Faculty of Medicine University of Indonesia,

Jakarta, Indonesia
} 
Periodontal inflammation is a periodontal disorder of high prevalence in the population. According to the Data Center, Ministry of Health of The Republic of Indonesia, periodontal disorder ranks on the $8^{\text {th }}$ position among the 10 main diseases of outpatients in the general hospitals. ${ }^{1}$ The severity of the disease is determined by the degree of clinical periodontal status. The periodontal status is influenced by local factors such as accumulation of plaque and calculus, and systemic factors such as hormonal imbalance, diabetes mellitus, nutrition, genetic, make up and the use of drugs. Removing calculus (scaling) as non-surgical periodontal therapy improves clinical periodontal status. ${ }^{1,2}$

The systemic condition primarily affects tissue defense mechanism/immunity which is determined by the periodontal immune response and can be evaluated by looking at local or systemic cellular immune response. The phagocytic function of polymorphonuclear leucocytes (PMN) represents systemic immune mechanism that is clinically important to determine immunity against infection. $3,4,5$

The main mediator of periodontal inflammation is IL-1 $\beta$. According to the Committee on Research, Science and Therapy, The American Academy of Periodontology, a periodontal infection, although minor, can affect the general health via systemic immune response. ${ }^{6}$ In vitro studies showed that cytokines (IL-1, TNF $\alpha$, and IFN $\gamma$ ) cause inhibition of insulin synthesis as well as insulin secretion, and therefore damaging $\beta$ cells of the pancreas. ${ }^{7,8}$

It is estimated, from 1994 until 2010, that the number of diabetic patients in the world population will increase two-fold reaching 239 million. ${ }^{9}$ Based on Indonesia's population growth tendencies today and according to the 2000 Diabetes Atlas (International Diabetes Federation), the number of people above 20 years of age in year 2020, is estimated to be 178 million, so that those who will be suffering from diabetes mellitus is estimated to be 8.2 million. ${ }^{1}$ Type 2 diabetes is suffered by $90 \%$ of diabetic patients. This type were usually detected at the age of 35-40 years. ${ }^{10}$

Hyperglycemia activates diacyl glycerol (DAG)proteinkinase $\mathrm{C}(\mathrm{PKC})$, thus increasing prostaglandin E2 (PGE2) and cytokine expressions that induce inflammation and periodontal tissue destruction processes. $^{11,12}$

In Indonesia, studies concerning the effect of scaling as non-surgical periodontal therapy on systemic immune response IL-1 $\beta$ level and phagocytotic function of PMN and control of blood glucose level in diabetic patients has never been carried out. Therefore, to improve the quality of care of diabetic patients, we conducted this study in order to give a sound scientific basis to establish Standard Operating Procedure of the management of periodontal diseases in diabetic patients.

The objective of this study was to evaluate the effect of scaling to immune response, and blood glucose level in controlled and uncontrolled type 2 diabetic patients.

\section{METHODS}

This was a clinical study on 60 controlled-diabetes mellitus (CDM) subjects and 60 uncontrolled-diabetes mellitus (UCDM) subjects in the Metabolic Endocrinology Clinic, Cipto Mangunkusumo Hospital Jakarta. The patients were on standard diet treatment and Oral Hypoglicemic Agents (OHA). This study was conducted from $2^{\text {nd }}$ April through $20^{\text {th }}$ August 2003. Ethical clearance was obtained from the Committee of the Medical Research Ethics of the Faculty of medicine, University of Indonesia. The subjects were divided into two groups, the intervention group and non-intervention group. Scaling was done in all intervension cases. Both groups were selected by simple random sampling. In this study we analyzed blood glucose and HbA1c levels, PMN phagocytotic function, and IL- $1 \beta$ level on both groups. Analysis was performed before intervention and 6 weeks after intervention. Paired t-test was used to compare the parameters before and after scaling, in CDM and UCDM subjects without and with intervention. The statistical analysis was performed using a computer with Stata 7.0 software.

\section{RESULTS}

\section{Effect of Scaling on Immune Response}

Table 1 shows a significant decrease in IL- $1 \beta$ level in UCDM intervention group as much as $7.67 \mathrm{pg} / \mathrm{mL}$ $(P=0.000)$, which was more than in the non-intervention group $(3.15 \mathrm{pg} / \mathrm{mL})$. Moreover, in the intervention group, scaling increased phagocytotic function of PMN significantly $(9.95 \%, P=0.005)$, while in the non-intervention group the increase of phagocytotic function was not significant $(2.9 \%, P=0.335)$. 


\section{Effect of Scaling on Blood Glucose Level}

After 6 weeks of scaling in both CDM and UCDM groups, the fasting blood glucose level, 2 hours postprandial blood glucose level, and $\mathrm{HbA} 1 \mathrm{c}$ level were all decreased. However, the increase was not significant except for the decrease of $0.54 \%$ in $\mathrm{HbA} 1 \mathrm{c}$ among UCDM group $(P=0.000)$.

\section{DISCUSSION}

Although there was a decreased in IL-1 $\beta$ level in the group without intervention (Table 1), but decrease was supposed to be an individual response to the test conducted (Hawthorne effect). ${ }^{12}$
The accumulation of bacterial plaque was the main local risk factor of periodontal inflammation. In this study, scalling as non-surgical periodontal therapy showed a decrease in IL- $1 \beta$ level and increased phagocytotic function of PMN significantly after scaling $(P$ $<0.05$ ). Interleukine- $1 \beta$ is the main mediator of periodontal inflammation, and the phagocytic function of PMN represents systemic immune mechanism that is clinically important to determine immunity against infection. Although the number of PMN is increased in periodontal infection, leucotoxin and protease produced by periodontal pathogen (Actinobacillus actinomycetemcomitans and Porphyromonas gingivalis) will induce chemotactic and phagocytotic defects; therefore causing decreased PMN phagocytic function. ${ }^{3-5}$

Table 1. Immune response in CDM and UCDM subjects prior to and 6 weeks after intervention

\begin{tabular}{|c|c|c|c|c|c|c|}
\hline & \multicolumn{2}{|c|}{ Without intervention } & \multirow[b]{2}{*}{$P$} & \multicolumn{2}{|c|}{ With intervention } & \multirow[b]{2}{*}{$P$} \\
\hline & $\begin{array}{l}\text { before } \\
(95 \% \mathrm{CI})\end{array}$ & $\begin{array}{c}\text { after } \\
(95 \% \mathrm{CI}) \\
\end{array}$ & & $\begin{array}{l}\text { before } \\
(95 \% \mathrm{CI})\end{array}$ & $\begin{array}{c}\text { after } \\
(95 \% \mathrm{CI})\end{array}$ & \\
\hline \multicolumn{7}{|l|}{ CDM } \\
\hline $\mathrm{IL}-1 \beta(\mathrm{pq} / \mathrm{mL})$ & $\begin{array}{c}26.39 \\
(24.78 ; 28.11)\end{array}$ & $\begin{array}{c}22.03 \\
(20.68 ; 23.45)\end{array}$ & 0.000 & $\begin{array}{c}23.96 \\
(22.19 ; 25.88)\end{array}$ & $\begin{array}{c}19.44 \\
(18.42 ; 20.52)\end{array}$ & 0.000 \\
\hline Phag.fc (\%) & $\begin{array}{c}50.86 \\
(46.13,56.08)\end{array}$ & $\begin{array}{c}66.45 \\
(60.77 ; 72.65)\end{array}$ & 0.000 & $\begin{array}{c}46.84 \\
(41.78 ; 52.51)\end{array}$ & $\begin{array}{c}61.96 \\
(57.12 ; 67.20)\end{array}$ & 0.000 \\
\hline \multicolumn{7}{|l|}{ UCDM } \\
\hline $\mathrm{IL}-1 \beta(\mathrm{pq} / \mathrm{mL})$ & $\begin{array}{c}26.44 \\
(24.63 ; 28.39)\end{array}$ & $\begin{array}{c}23.29 \\
(21.85 ; 24.83)\end{array}$ & 0.001 & $\begin{array}{c}28.08 \\
(26.61 ; 29.63)\end{array}$ & $\begin{array}{c}20.41 \\
(19.01 ; 21.91)\end{array}$ & 0.000 \\
\hline Phag.fc (\%) & $\begin{array}{c}57.54 \\
(51.93,63.76)\end{array}$ & $\begin{array}{c}60.44 \\
(54.56 ; 66.95)\end{array}$ & 0.335 & $\begin{array}{c}44.99 \\
(40.72 ; 49.71)\end{array}$ & $\begin{array}{c}54.94 \\
(50.68 ; 59.57)\end{array}$ & 0.005 \\
\hline
\end{tabular}

Table 2. Glucose level of CDM and UCDM patients prior to and 6 weeks after intervention

\begin{tabular}{|c|c|c|c|c|c|c|}
\hline \multirow{2}{*}{ Glucose level } & \multicolumn{2}{|c|}{ Without intervention } & \multirow[b]{2}{*}{$P$} & \multicolumn{2}{|c|}{ With intervention } & \multirow[b]{2}{*}{$P$} \\
\hline & $\begin{array}{c}\text { before } \\
(95 \% \mathrm{CI})\end{array}$ & $\begin{array}{c}\text { after } \\
(95 \% \mathrm{CI})\end{array}$ & & $\begin{array}{c}\text { before } \\
(95 \% \mathrm{CI})\end{array}$ & $\begin{array}{c}\text { after } \\
(95 \% \mathrm{CI})\end{array}$ & \\
\hline \multicolumn{7}{|l|}{ CDM } \\
\hline HbA1c (\%) & $\begin{array}{c}6.26 \\
(597 ; 6.56)\end{array}$ & $\begin{array}{c}6.32 \\
(6.07 ; 6.59)\end{array}$ & 0.534 & $\begin{array}{c}6.25 \\
(6.05 ; 6.46)\end{array}$ & $\begin{array}{c}6.16 \\
(5.93 ; 6.38)\end{array}$ & 0.138 \\
\hline Fasting G & $\begin{array}{c}120.91 \\
(113.72 ; 128.56)\end{array}$ & $\begin{array}{c}124.80 \\
(117.46 ; 132.61)\end{array}$ & 0.394 & $\begin{array}{c}117.82 \\
(110.96 ; 125.09)\end{array}$ & $\begin{array}{c}114.64 \\
(108.89 ; 120.69)\end{array}$ & 0.192 \\
\hline 2 hour PP & $\begin{array}{c}180.53 \\
(164.05 ; 198.67) \\
\end{array}$ & $\begin{array}{c}181.65 \\
(168.67 ; 195.63) \\
\end{array}$ & 0.903 & $\begin{array}{c}201.15 \\
(186.28 ; 271.20) \\
\end{array}$ & $\begin{array}{c}197.52 \\
(184.22 ; 211.78)\end{array}$ & 0.429 \\
\hline \multicolumn{7}{|l|}{ UCDM } \\
\hline HbA1c (\%) & $\begin{array}{c}8.16 \\
(7.84 ; 8.51)\end{array}$ & $\begin{array}{c}7.94 \\
(7.05 ; 8.42)\end{array}$ & 0.311 & $\begin{array}{c}9.24 \\
(8.67 ; 9.85)\end{array}$ & $\begin{array}{c}8.70 \\
(8.13 ; 9.31)\end{array}$ & 0.000 \\
\hline Fasting G & $\begin{array}{c}159.22 \\
(145.02 ; 174.81)\end{array}$ & $\begin{array}{c}169.95 \\
(153.43 ; 182.25)\end{array}$ & 0.065 & $\begin{array}{c}177.46 \\
(157.19 ; 200.31)\end{array}$ & $\begin{array}{c}170.64 \\
(150.16 ; 193.91)\end{array}$ & 0.406 \\
\hline 2 hour PP & $\begin{array}{c}229.92 \\
(197.68 ; 267.41)\end{array}$ & $\begin{array}{c}232.97 \\
(207.91 ; 261.04)\end{array}$ & 0.944 & $\begin{array}{c}256.06 \\
(233.99 ; 280.20)\end{array}$ & $\begin{array}{c}255.21 \\
(231.86 ; 280.92)\end{array}$ & 0.995 \\
\hline
\end{tabular}


In term of IL-1 $\beta$ level, our finding was consistent with the finding of Gamonal et al. who studied local IL-1 $\beta$ level in the gingival crevicular fluid and found that IL-1 $\beta$. level was correlated to periodontal status because the absence of calculus and bacterial plaque decreased the antigenic stimulation and thus decreased chemokine production. $^{14}$

After 6 weeks of non-surgical treatment (Table 2), the fasting blood glucose level, 2 hours postprandial blood glucose level and HbA1c level were all decreased; however, the decrease was not statistically significant except for decreased HBA1c level among UCDM group $(P=0.000)$.

The reason of the statistically non significant decrease might be due to the many factors that affected blood glucose level, i.e. lipid level, obesity, hypertension, insulin level, inactivity, stress, smoking, age, etc. ${ }^{15}$ This decrease was in accordance with the finding of $\mathrm{Fu}$ et al. that showed controlling periodontal inflammation improved metabolism of type 2 diabetic patients. ${ }^{16}$

Previous studies showed that cytokines directly stimulated iNOS (inducible nitric oxide synthase) expression and increased NO (nitric oxide) production by $\beta$ cells, and then NO indirectly damaged $\beta$ cells. Cytokines also stimulated iNOS expression through non-endocrine cells (macrophages and endothelial cells), and the NO produced can cause damage to $\beta$ cells. Furthermore, cytokines also affected tyrosine kinase receptor function and caused insulin resistance. ${ }^{7,8}$ Control of inflammation was shown to decrease cytokine level so that iNOS stimulation and NO production by $\beta$ cells was decreased resulting in decreased $\beta$ cells damage and stimulated insulin secretion. ${ }^{11}$

In diabetes mellitus, advanced glycosilation end product (AGE) is bound to monocytes, and thus increasing chemotaxis, IL-1 $\beta$. and TNF $\alpha$ levels, and activates macrophages and osteoclasts. Moreover the binding of AGE to the endothelial cells cause cell function changes, vascular lesion and vasocontriction. Hyperglycemia activates DAG-PKC, thus increasing PGE2 and cytokine expression, ${ }^{11}$ while control of periodontal inflammation will decrease chemotaxis and cytokine expression.

The significant decrease of HbA1c in UCDM in this study was consistent with previous finding reported that the decrease of HbAlc level occurred within 3 weeks after one week achieving a controlled fasting blood glucose level, ${ }^{17}$ and it was consistent with the finding of Rodrigues et al. that showed that 3 months after local treatment there was a significant decrease in HbA1c level $(P<0.05)$ and insignificant decrease in fasting blood glucose level $(P>0.05) .{ }^{18}$ This study suggests that scaling as non-surgical periodontal therapy resulted in decreased blood glucose level in type 2 diabetic patients, and can be used to overcome the problems of diabetic patients with periodontal disease. Therefore, we recommend that especially for patients suffering from DM to maintain their periodontal health by performing plaque and calculus control periodically to reduce the risk factors affecting type 2 $\mathrm{DM}$, and at the same time to control their blood glucose level.

In conclusion, scaling increased periodontal status, decreased IL-1 $\beta$ level, and increased phagocytic function significantly. Furthermore, scaling decreased fasting and 2 hours postprandial blood glucose levels and also HbAlc level, but the decreases were not statistically significant except for the decrease in HbA1c level in UCDM group.

\section{REFERENCES}

1. Pusat Data Depkes RI. Profil Kesehatan Indonesia 2001 Menuju Indonesia Sehat 2010. Jakarta: Depkes RI; 2002.

2. Novak MJ. Classification of diseases and conditions affecting the periodontium. In: Newman MG, Takei HH, Carranza FA, editors. Clinical Periodontology. $9^{\text {th }}$ ed. Philadelphia: WB Saunders; 2002.p.64-72.

3. Lehmann AK, Sornes S, Halstensen A. Phagocytosis: measurement by flowcytometry. JIM. 2000; 243: 229-42.

4. Fokkema SJ. Susceptibility to destructive periodontal disease. In: Fokkema SJ, editor. Susceptibility to periodontitis; studies with LPS-stimulated whole blood cell cultures. Wageningen: Ponsen \& Looijen BV;2002. p.10-4.

5. Haake SK, Huang GT. Molecular biology of the hostmicrobe interaction in periodontal diseases: selected topics. In: Newman MG, Takei HH, Carranza FA, editors. Clinical Periodontology. $9^{\text {th }}$ ed. Philadelphia: WB Saunders; 2002.p.153-8.

6. Committee Research, Science and Therapy, The American Academy of Periodontology. Periodontal disease as potential risk factor for systemic diseases. J Periodontol. 1998; 69: 841-50.

7. Nassar H, Kantarci A, Van Dyke TE. Diabetic periodontitis: a model for activated innate immunity and impaired resolution of inflammation. Periodontol 2000.2007;43: 233-44.

8. Thomas HE, Darwiche R, Corbett JA, Kay TWH. Interleukin-1 plus $\gamma$-interferon-induced pancreatic $\beta$-cell dysfunction is mediated by $\beta$-cell nitric oxide production. Diabetes. 2002; 51(2): 311-16.

9. Pusat Data Kesehatan. Depkes RI. Profil Kesehatan Indonesia. Jakarta: Depkes RI; 1998.

10. Cotran RS, Luman V, Collin T. The Endocrin. In: Cotran RS, Kumar V, Collins T, editors. Pathology Anatomy Basis of 
Diseases. $6^{\text {th }}$ ed. Philadelphia: WB Saunders; 1999.p. 913-26.

11. Sheetz MJ, King GL. Molecular understanding of hyperglycemia's adverse effects for diabetic complications. JAMA.2002;288:2579-88.

12. Gemmell E, Yamazaki K, Seymour GJ. The role of T cells in periodontal disease: homeostasis and autoimmunity. Periodontol 2000.2007; 43:14-30.

13. Nishimura F, Iwamoto Y, Soga Y. The periodontal host response with diabetes. Periodontol 2000.2007;43:245-7.

14. Gamonal J, Acevedo A, Bascones A, Jorge O, Silva A. Levels of interleukin-1 beta, -8 and -10 and RANTES in gingival crevicular fluid and cell populations in adult periodontitis patients and the effect of periodontal treatment. J Periodontol. 2000;71(10):1535-45.
15. Askandar Tjokroprawiro. Oxidative stress in diabetes mellitus: an update (focus on clinical implications). JAFES.2002; 20(suppl-1):13-22.

16. Fu Y, Ling J, Deng $Y$. The effect of non-surgical periodontal therapy on blood sugar level of non-insulin dependent diabetes mellitus diabetics with periodontitis. Zhonghua Kou Qiang Yi Xue Zu Zhi. 2000; 35(6):444-6.

17. Siregar P. Menentukan waktu tercapainya nilai normal gliko-Hb pada penderita DM yang mendapat obat anti diabetes [Tesis]. Jakarta; Universitas Indonesia: 2004.

18. Rodrigues DC, Taba MJ, Novaes AB, Souza SL, Grisi MF. Effect of non-surgical periodontal therapy on glycemic control in patients with type 2 diabetes mellitus. J Periodontol. 2003; 74 (9): 1361-7. 